\title{
PARASITE FAUNA DIVERSITY IN RED FOX (Vulpes vulpes) FROM NATURAL AND ANTHROPIZED ECOSYSTEMS OF THE REPUBLIC OF MOLDOVA
}

\author{
Oleg Chihai ${ }^{1}$, Ștefan Rusu${ }^{1}$, Nina Talambuță², Victoria Nistreanu ${ }^{1}$, \\ Alina Larion', Anatol Savin', Nicolae Naforniță ${ }^{3}$
}

\author{
${ }^{1}$ Instite of Zoology, Chișinău, Republic of Moldova \\ ${ }^{2}$ Free International University of Moldova, Chișinău, Republic of Moldova \\ ${ }^{3}$ State Agrarian University of Moldova, Chișinău, Republic of Moldova \\ E-mail: olegchihai@yahoo.com
}

\begin{abstract}
The study of the diversity of the parasite fauna in the investigated foxes showed a high level of infestation $(100 \%)$. The taxonomy of parasitofauna in foxes includes 12 parasitic invasions (Isospora canis - 14,3\%, Alaria alata - 51,0\%, Mesocestoides lineatus - 21,7\%, Taeniidae spp - 27,0\%, Syphacia obvelata $-17,0 \%$, Strongyloides stercoralis $-13,3 \%$, Toxocara canis $-59,0 \%$, Toxascaris leonina $-65,5 \%$, Ancylostoma caninum $-8,7 \%$, Trichuris vulpis $-26,1 \%$, Trichuris muris $-4,4 \%$, Capilaria hepatica $-35,0 \%$ ), which belong to 5 classes, 10 families, 11 genera and about 12 species. The share of species from the Sporozoa class is $8.3 \%$, from the Trematoda class $-8.3 \%$, from the Cestoda class $-16.7 \%$, from the Secernentea class $-41.7 \%$ and from the Adenophorea class $-25.0 \%$. Analyzing the parasitic species on epidemiological criterion, it was found that 10 species $(83.3 \%)$ with large spread have zoonotic impact (A. alata, M. lineatus, Taenia spp., S. obvelata, S. ratti, T. canis, T. leonina, A. caninum, C. hepatica, T. vulpis) with a major risk to public health, and the identified invasions (100\%) can parasitize domestic animals, as well as game fauna.
\end{abstract}

\section{Introduction}

Canids play a key role in the stability of the development cycles of a large number of parasitic species, including those with zoonotic impact. These animals pollute the environment with parasitic forms, which is why they pose a major danger to humans and the environment [19; 20; 1]. The presence of these animals in close contact with humans is a potential risk of increased infection, through contact with soil, vegetables, grapes and berries contaminated with parasitic forms $[4 ; 7]$.

The close human relationship with canids and the common environment can increase the risk of human infection with vector-borne zoonotic pathogens, while wild mammals in their vicinity may act as reservoirs for such pathogens [9]. The evaluation of the population of Vulpes vulpes in the Republic of Moldova according to the number of reproductive burrows in the spring period, highlighted an increased density of foxes by 7-8 times [13].

Helminthfauna in $V$. vulpes in the Republic of Moldova previously (1958-1984) was studied and described by O. Anreyko. The author describes in this host several species of parasites as follows: class Trematoda Alaria alata; class Cestoda Dipilidium caninum, Mesocestoides lineatus, Taenia cressiceps; class Nematoda Capillaria plica, Thominx aerophilus, Trichocephalus vulpis, Trichinella spiralis, Uncinaria stenocephala, Gnatostoma spingerum, Toxascaris leonina, Toxocara canis [17].

The prevalence of parasites identified in V. vulpes in Romania was for: Eimeria spp. 20.4\%, Alaria alata $6.9 \%$, Mesocestoides lineatus $31.5 \%$, Taenia pisiformis 24.5\%, Dypilidium can- 
inum $6.0 \%$, Toxocara canis $39.4 \%$, Ancylostoma caninum $14.81 \%$, Uncinaria stenocephala $10.2 \%$, Pterigodermatites affinis $6.5 \%$, Trichocephalus vulpis $21.8 \%$ [5].

Similar studies performed in Ukraine has revealed in V. vulpes several parasitic species: Pearsonema plica 13.2\%, Aonchotheca putorii 0.6\%, Eucoleus aerophilus 12.0\%, Trichuris vulpis $18.8 \%$, Trichinella spiralis $0.6 \%$, Ancylostoma caninum $0.6 \%$, Uncinaria stenocephala 27.1\%, Crenosoma vulpis 6.2\%, Molineus patens 3.6\%, Toxascaris leonina 39.2\%, Toxocara canis $22.9 \%$, Spirocerca arctica $0.6 \%$, Pterygodermatites affinis $5.4 \%$, Heligmosomum costellatum $0.6 \%$, Syphacia agraria 0.6\% [15].

Nematoda helminths in V. vulpes in Polonia were identified as follows: Toxocara canis $30.2 \%$, Toxascaris leonine 26.0\%, Uncinaria stenocephala $34.0 \%$, Trichuris vulpis $11.9 \%$ [14].

Parasite fauna monitoring in foxes and specifying their epidemiological role is of major importance for preventing the transmission of pathogens to animals and humans, which are involved in the evolutionary cycles of parasites. The bibliographic data described above denote the purpose of this paper, which provides the bioecological study on the role of canids (Vulpes vulpes) in the transmission of parasitic species in the zoonotic and epizootic chain of natural and anthropogenic ecosystems.

\section{Materials and methods}

Parasitological investigations, according to the methods Popova, Baermann, Fuileborn, Darling, of the successive washing [18], were performed in the laboratory of Parasitology and Helminthology of the Institute of Zoology, on biological samples collected from foxes from natural and anthropized biotopes from different areas of the Republic of Moldova. In the ovocoproscopic diagnosis, the Teneidae oncospheres (T. hydatigena, T. pisiformis, M. multiceps, $M$. serialis E. granulosus, E. multilocularis) are very similar to each other, which is why they are noted as Tenea sp. oncospheres [8].

The parasitological evaluation is based on the determination of the prevalence (\%), intensity (specimens / animal) and abundance (specimens / plot) of the parasitic species in the investigated canids.

\section{Results and discussions}

In recent years, many vector-borne diseases have (re) emerged and spread, due to global and / or local changes that have led to the invasion of new arthropod-vector species, improved their vector capacity, or the introduction and establishment of territory of new species of pathogens [12].

Research on the role of wild canids in the spread of parasitic species in the zoonotic and epizootic chain of natural and anthropogenic ecosystems began with the evaluation of the fox population by the number of breeding population in spring. The fox is quite numerous in the southern (10 ind./1000 ha) and in the central part (9 ind./1000 ha), having low density in the northern part (6.2 ind./1000 ha). At the spring evaluations, the fox was observed with densities of $5.5 \mathrm{ind} . / 1000$ ha in the agricultural funds. Thus, in the agricultural ecosystems in the spring were evaluated about 15000 foxes, over 6000 foxes have been registered in localities and 3700 
foxes were counted in the forest ecosystems, total number of about 25000 individuals. Toward the end of 2020, in the autumn period, the fox population number was of 35000 individuals.

The fox population decreased in the last years, while in 2014-2017 its density was of 14 - 16 ind. / 1000 ha. The concentration of foxes in forested ecosystems and in localities is an ecological-ethological adaptation caused by trophic resources availability and the stability factor particular to these types of ecosystems [13].

The study of the parasite communities diversity in fox highlighted several species of parasites (tab.1). The species Isospora canis from the Sporozoa class was identified with a prevalence of $14.3 \%$ and an intensity of 2-8 oocysts. The Trematoda class was represented by Alaria alata with a prevalence of $51.0 \%$ and an intensity of 1-2 eggs. From the class Cestoda there was identified Mesocestoides lineatus with a prevalence of $21.7 \%$ and an intensity of 3-15 eggs and Taeniidae spp with $27.0 \%$, respectively (3-4 oncospheres). The species from the class Secernentea are represented by Syphacia obvelata with a prevalence of $17.0 \%$ and an intensity of 3-4 eggs in the microscopic field, respectively, Strongyloides stercoralis - 13.3\%, (50-100 larvae), Toxocara canis - 59.0\% , (2-5 eggs), Toxascaris leonina - 65.5\%, (12 eggs), Ancylostoma caninum $-8.7 \%$, (1 egg). The parasitic invasions from the class Adenophorea were represented by Trichuris vulpis with a prevalence of $26.1 \%$ and an intensity of 2 eggs in the microscopic field, respectively Trichuris muris - 4.4\%, (2-3 eggs), Capillaria hepatica - 35.0\%, (3-4 transit eggs). An important fact is that $100 \%$ of the total number of parasitologically investigated foxes were infested.

Table 1. Parasite fauna in Vulpes vulpes

\begin{tabular}{|c|c|c|c|c|}
\hline Class & Family & Species & $\begin{array}{c}\begin{array}{c}\text { Prevalence } \\
(\%)\end{array} \\
\end{array}$ & $\begin{array}{c}\text { Intensi- } \\
\text { ty (sp.) }\end{array}$ \\
\hline Sporozoa & Eimeriidae & Isospora canis (Levine, 1977) & 14,3 & $2-8$ ouă \\
\hline Trematoda & Diplostomidae & Alaria alata (Goeze, 1792) & 51,0 & $1-2$ ouă \\
\hline \multirow{2}{*}{ Cestoda } & Taeniidae & Taenia spp & 27,0 & 3-4 ouă \\
\hline & Mesocestoididae & Mesocestoides lineatus (Goeze, 1782) & 21,7 & 3-15 ouă \\
\hline \multirow{5}{*}{$\begin{array}{l}\text { Secernen- } \\
\text { tea }\end{array}$} & Oxyuridae & Syphacia obvelata (Rudolphi, 1802) & 17,0 & 3-4 ouă \\
\hline & Strongyloididae & Strongyloides stercoralis (Bavay, 1876) & 13,3 & $\begin{array}{c}50-100 \\
\text { larve }\end{array}$ \\
\hline & \multirow{2}{*}{ Ascarididae } & Toxocara canis (Werner, 1782) & 59,0 & 2-5 ouă \\
\hline & & Toxascaris leonina (Linstow, 1902) & 65,5 & 12 ouă \\
\hline & Ancylostomatidae & Ancylostoma caninum (Ercolani, 1859) & 8,7 & $1 \mathrm{ou}$ \\
\hline \multirow{3}{*}{$\begin{array}{l}\text { Adenopho- } \\
\text { rea }\end{array}$} & \multirow{2}{*}{ Trichuridae } & Trichuris vulpis (Froelich, 1789) & 26,1 & 2 ouă \\
\hline & & Trichuris muris (Scrank, 1788) & 4,4 & 2-3 ouă \\
\hline & Capilariidae & Capilaria hepatica (Bancroft, 1893) & 35,0 & $3-4$ ouă \\
\hline
\end{tabular}

Similar research conducted previously (1958-1984) in the Republic of Moldova revealed several species of parasites as follows: Alaria alata $-28,9 \%$, Dipilidium caninum- 3,7\%, Mesocestoides lineatus- 59,3\%, Taenia cressiceps - 3,71\%,Capillaria plica- 11,2\%, Thom- 
inx aerophilus-40,8\%, Trichocephalus vulpis - 3,7\%, Trichinella spiralis $-7,4 \%$, Uncinaria stenocephala - 29,7\%, Crenosuma vuples - 3,7\%, Toxascaris leonina-81,5\%, Toxocara canis $-40,8 \%$ [17]. Comparing the previous data with the recent ones, insignificant differences were found, but with the maintenance of a high level of infestation.

From taxonomic point of view the parasitic species identified in the fox fall into 5 classes, 10 families, 11 genera and about 12 species, including 1 parasitic species of the class Sporozoa, 1 species of the class Trematoda, 2 species of the class Cestoda, and 4 species of the class Secernentea and 3 species of the class Adenophorea.

The helminthofauna hierarchy was evaluated according to the prevalence level,being identifying 3 eudominant species (Toxascaris leonina, Toxocara canis, Alaria alata) with 65,5 51,0\%, 3 dominant species (Capilaria hepatica, Trichuris vulpis, Taenia spp, Mesocestoides lineatus) with 35,0 - 21,7\%, 3 subdominant species (Syphacia obvelata, Isospora canis, Strongyloides stercoralis) with 35,0 - 21,7\% and 2 rare encountered species (Ancylostoma caninum, Trichuris muris) with $8,7-4,4 \%$.

The development feature denotes 9 species that develop according to the monoxene model (Syphacia obvelata, Capilaria hepatica, Trichuris muris, Strongyloides stercoralis), species of Taenia have dixen evolution cycle (Taenia spp), one specie with trixen development (Mesocestoides lineatus) and one species with tetraxen evolution (Alaria alata).

The epidemiological feature highlights 2 categories of parasitosis, zoonotic and canine specific. Zoonotic parasitosis are caused by 10 parasitic species, including 1 species of the class Trematoda (A. alata), 1 genus and several species of the class Cestoda (M. lineatus, Taenia spp.), 5 species of the class Secernentea (S. obvelata, S. ratti, T. canis, T. leonina, A. caninum) and 2 species of the class Adenophorea (C. hepatica, T. vulpis), while 2 species induce diseases particular to canids, including 1 species of the class Sporozoa (Isospora canis) and 1 species of the class Adenophorea (T. muris).

Table 2. Epidemiologic characteristics of parasite fauna in fox

\begin{tabular}{|c|c|c|c|c|c|c|}
\hline \multirow{2}{*}{ Impact } & \multicolumn{5}{|c|}{ Class } & \multirow[b]{2}{*}{ Total } \\
\hline & Sporozoa & Trematoda & Cestoda & Secernentea & Adenophorea & \\
\hline Zoonotic & - & A. alata & $\begin{array}{l}\text { Taenia spp } \\
\text { M. lineatus }\end{array}$ & $\begin{array}{l}\text { S. obvelata } \\
\text { S. stercoralis } \\
\text { T. leonina } \\
\text { T. canis } \\
\text { A. caninum }\end{array}$ & $\begin{array}{l}\text { C. hepatica } \\
\text { T. vulpis }\end{array}$ & $\begin{array}{c}10 \\
(83,3 \%)\end{array}$ \\
\hline Fox & I. canis & - & - & - & T. muris & $\begin{array}{c}2 \\
(16,7 \%)\end{array}$ \\
\hline
\end{tabular}

Analyzing the parasitic invasions on epidemiological criteria, we find that 10 species $(83.3 \%)$ with increased spread have zoonotic impact (A. alata, M. lineatus, Taenia spp., $S$. obvelata, S. ratti, T. canis, T. leonina, A. caninum, C. hepatica, T. vulpis) with major risk for public health, andtwo of them are particular for canids (16,7\%). 
Zoonotic parasitosis are of major epidemiological importance because they have a direct impact on human health, and carnivores are definitive hosts or reservoirs of more than 60 parasitic species with zoonotic impact $[7 ; 6]$.

Several gastrointestinal parasites of canids, especially Toxocara spp., Ancylostoma spp., Echinococcus spp., Dipylidium spp., Taenia spp. are considered species with increased zoonotic potential $[3 ; 2]$. According to some authors, zoonotic parasites can be divided into 4 groups $[16 ; 3 ; 10 ; 11]$.

From the research results we find zoonotic parasites that directly infect humans through animals (Toxascaris leonina, Toxocara canis); saprozoonotic parasites that are transmitted through soil or water contaminated with parasitic forms (Ancylostoma caninum, Strongyloides stercoralis); metazoonotic parasites that infect humans through intermediate invertebrate hosts (Alaria alata, Dipylidium caninum); cyclozoonotic parasites that infect humans through vertebrate intermediate hosts (Echinococcus granulosus, Taenia spp).

At the same time, it is important that all identified parasitic species $(100 \%)$ have an epizootic impact, which indicates that they can also infest domestic animals, as well as wild animals, which is why they pose an eminent danger to the gamespecies.

These parasitosis cause economic damage to domestic and wild animals, causes considerable damage to their number, including the integrity of the spectrum of main and complementary species that ensure the hunting fund.

Monitoring the parasitofauna in canids, highlighting the epidemiological role, is of major importance for preventing the transmission of pathogens to animals and humans, which are involved in the evolutionary cycles of parasites.

The results obtained denote a rich diversity of parasitic species with increased prevalence and intensity. This is due to the considerable increase in the number of foxes (7-8 times), as well as the ecological plasticity of this species with a tendency to synanthropy.

These are the key factors in the emergence and maintenance of outbreaks of parasitosis in natural and anthropogenic ecosystems.

The results obtained from parasitological investigations represent the premise of developing new procedures to control / reduce parasitosis in wild canids in order to strengthen bioecological and epidemiological security in natural and anthropogenic ecosystems.

The studies were performed within the State Program projects 20.80009.7007.12 and 20.80009.7007.02.

\section{Conclusions}

The evaluation of the population of Vulpes vulpes according to the number of reproductive burrows during the spring, showed an increased density of foxes, this being about 9individuals / 1000 ha, compared to the normal density of 1- 2 individuals / 1000 ha, which indicates a considerable increase of 4-5 times.

The study of the diversity of parasite communities in the investigated foxes, denotes an increased level of infestation with parasitic species - of $100 \%$.

The taxonomy of parasitofauna in investigated foxes includes 12 parasitic invasions (Isos- 
pora canis, Alaria alata, Mesocestoides lineatus, Taeniidae spp, Syphacia obvelata, Strongyloides stercoralis, Toxocara canis, Toxascaris leonina, Ancylostoma caninum, Trichuris hepis) the parasitic species identified in the fox fall into 5 classes, 10 families, 11 genera and about 12 species. The share of species in the Sporozoa class is $8.3 \%$, in the Trematoda class $-8.3 \%$, in the Cestoda class $-16.7 \%$, in the Secernentea class - $41.7 \%$ and in the Adenophorea class $25.0 \%$.

As epidemiological criteria, 10 species $(83.3 \%)$ with increased prevalence have zoonotic impact (A. alata, M. lineatus, Taenia spp., S. obvelata, S. ratti, T. canis, T leonine, A. caninum, C. hepatica, T. vulpis) with a major risk to public health, and all identified invasions $(100 \%)$ can parasitize domestic animals, as well as game fauna.

\section{Bibliography}

1. Abdi, J., Asado-lahi, Kh., Maleki, M.H., Ashrafi Hafez A. Prevalence of Helminthes Infection of Stray Dogs in Ilam Province. J. Paramedical Sciences (4). 2013. P. 47-50.

2. Chaulagain, S. and Ghimire, L. Prevalence of gas $\neg$ trointestinal zoonotic helminths in dogs of Kathmandu, Nepal. International Journal of Infection and Microbiology. 2013. 2: 91-94.

3. Chen, J., Xu, M.J., Zhou, D.H., Song, H.Q., Wang, C.R. and Zhu, X.Q. Canine and feline parasitic zoonoses in China. J.Parasites and Vectors. 2012. 5: P. 1005-1011.

4. Dalimi, A., Sattari, A. and Motamedi, G. A study on intestinal helminthes of dogs, foxes and jackals in the west $\neg$ ern part of Iran. Veterinary Parasitology. 2006142: 129-133.

5. Hora Florin Ştefan. Parazitoze gastrointestinale la vânatul mamifer din vestul României. Teza dedoctorat. Timişoara, 2017. $168 \mathrm{p}$.

6. Kohansal, M.H., Fazaeli, A., Nourian, A., Haniloo, A., Kamali, K. Dogs' gastrointestinal parasites and their association with public health in Iran. J. Veterinary Researces. 2017. 61: 189195.

7. Macpherson, C.N., Torgerson, P.R. Dogs and Cestode Zoonoses. Dogs, Zoonoses and Public Health. CABI, Oxon, UK. 2013.

8. Mircean, V., Cozma, V., Gyorke, A. Diagnosti coproparazitologic ]n bolile parazitare laanimale. Cluj-Napova, Risoprint, 2011. 344 p.

9. Otranto, D., Dantas-Torres, F., Brianti, E., Traversa, D., Petric, D., Genchi, C., Capelli, G. Vector-borne helminths of dogs and humans in Europe. J.Parasites and Vectors. 2013. 6:16. P. 1-14.

10. Overgaauw, P.A., Van Zutphen, L., Hoek, D., Yaya, F.O., Roelfsema, J., Pinelli, E., Van Knapen, F. and Kortbeek, L.M. Zoonotic parasites in fecal samples and fur from dogs and cats in the Netherlands. . Veterinary Researces. 2009. 163: P. 115-122.

11. Perera, P., Rajapakse, R. and Rajakaruna, R. Gastrointestinal parasites of dogs in Hantana area in the Kandy district. J. of the National Science Foundation of Sri Lanka. 2013. 41. P. 81-91.

12. Rogers, D.J., D.J.,Randolph, S.E. Climate change and vector-borne diseases. J. Advances in Parasitology. 2006. Vol. 62. P. 345 - 381.

13. Savin A., Caisîn V., Grosu G. Dinamica efectivelor și impactul unor prădători în ecosistemele Republicii Moldova. „Actual problems of zoology and parasitology: achievements and prospects”, international symposium. Chişinău, 2017. P. 403 - 404.

14. Tylkowska, A., Pilarczyk, B., Tomza Marciniak A., Pilarczyk, R. The prevalence of intestinal nematodes among red foxes (Vulpes vulpes) in north-western Poland. Acta Veterinaria Scandinavica. 2021, 63:19. P. 1-7. 
15. Varodi, E.I., Malega, A.M., Kuzmin Y.I., Kornyushin V.V. Helminths of wild predatory mammals of ukraine. Nematodes. Vestnik zoologii. 2017, 51(3): 187-202,

16. Youn, H. Review of zoonotic parasites in medical and veterinary fields in the Republic of Korea. Korean J. Parasitology. 2009. 47 Suppl:P.133-141.

17. Андрейко О.Ф. Паразиты млекопитающих Молдавии. Кишинев: Штиинца, 1973. 185 с.

18. Котельников Г. Гельминтологические исследования животных и окружающей среды. Москва: Колос, 1984. 208 с.

19. Петров, Ю.Ф., Крючкова, Е.Н., Шахбиев, Х.Х. Контаминация объектов внешней среды яйцами и личинками Ancylostoma caninum и Uncinaria stenocephala в европейской части России. Российский паразитологический журнал. 2012. № 1. С. 42-44.

20. Фадеева, А.Н., Горчакова Н.Г. Паразитарные болезни домашних плотоядных в условиях Нижнего Новгорода. Ветеринария. 2016. №. 6. С. 33-35. 